\title{
Caffeine and blood flow
}

\section{Gary F. Merrill}

Department of Cell Biology and Neuroscience, Division of Life Sciences, Rutgers University, New Brunswick and Piscataway, New Jersey 08901, USA.

Corresponding Author: Garry F Merrill, Cell Biology and Neuroscience, Division of Life Sciences School of Arts and Sciences, Rutgers University, New Brunswick and Piscataway, New Jersey 08901, USA.

Received date: March 11, 2021; Accepted date: March 30, 2021; Published date: April 06, 2021

Citation: Gary F. Merrill (2021) Caffeine and blood flow, Clinical Medical Reviews and Reports. 3(4); DOI:10.31579/2690-8794/078

Copyright: () 2021, Garry F Merrill, This is an open access article distributed under the Creative Commons Attribution License, which permits unrestricted use, distribution, and reproduction in any medium, provided the original work is properly cited.

\begin{abstract}
Arguably, caffeine is the world's leading drug of choice. It is estimated that in the U.S. and Europe at least ninety per cent of the adult populations consume caffeine-containing beverages several times each day. It is also known that consumers prefer their hot coffee to be in the range of $45-60^{\circ} \mathrm{C}$ (i.e. as hot as $140^{\circ} \mathrm{F}$ ). If such a drink is spilled on the exposed skin it can cause full-thickness, third degree burns within 5 seconds. These are the kinds of burns that produce permanent damage and scarring for life. The prudence of consuming hot coffee and other hot drinks at such temperatures is questionable, especially when children and adolescents are involved.
\end{abstract}

Keywords: caffeine; blood flow; hot drinks

\section{Introduction}

Arguably, caffeine is the world's leading drug of choice [1-5]. It is estimated that in the U.S. and Europe at least ninety per cent of the adult populations consume caffeine-containing beverages several times each day [1-5]. It is also known that consumers prefer their hot coffee to be in the range of $45-60^{\circ} \mathrm{C}$ (i.e. as hot as $140^{\circ} \mathrm{F}$ ) [6-10]. If such a drink is spilled on the exposed skin it can cause full-thickness, third degree burns within 5 seconds [6-10]. These are the kinds of burns that produce permanent damage and scarring for life $[8,10]$. The prudence of consuming hot coffee and other hot drinks at such temperatures is questionable, especially when children and adolescents are involved.

Caffeine's vehicles of delivery are well-known and include: coffee, energy drinks, pre-workout mixtures, soft drinks, sports drinks, tea, and others (e.g. candy, chewing gum, ice cream, and yogurt). They also include exercise ergogenic aids such as pills, caplets and capsules (personal communications with research subjects) all of which are unregulated and contain unidentified fillers. According to the USDA, one 8-ounce cup of coffee (240 milliliters) contains about 100 milligrams of caffeine. Among fifty three sports drinks and dietary supplements analyzed by the USDA, twenty seven products provided 100-200 mg caffeine (per manufacturer's labels), eleven had 200-400 mg, another eleven contained 400-600 mg, and four boasted 700-800 mg of caffeine.

The cognitive and psychosomatic effects of caffeine have also been explored in recent years [11-15]. Who has not met a university student who uses coffee and other caffeinated products to stay awake cramming for exams? Following are a few student testimonials describing their experiences with the drug.

Student $1 .$. "I did not start drinking coffee every day until high school. If I do not drink caffeine for one day, or do not get my coffee early enough in the day, I will usually get a headache from lack of caffeine"...
Student 2..."Caffeine, arguably the most abused and addictive legal substance in modern times, somehow weasels its way into many innocent lifestyles under the guise 'America Runs on Dunkin.' I quickly succumbed to caffeine's grasp as soon as I entered the university... With the nearby coffee shops closed (COVID-19) it was always a hassle to obtain coffee when I needed it for exams. I resorted to seeking the only accessible beverage with caffeine, a sixteen fluid ounce Monster Energy drink (172 mg caffeine)...My relationship with caffeine quickly expanded to two cans per night for an exam... and on some especially rough testing days, even three cans per night (i.e. 344-516 mg caffeine)"...

Student no. 3--- "During the sophomore year of high school I had my first significant experiences with caffeine as a stimulant. On the lacrosse team, I was introduced to "pre-work out" mixes (150-300 mg caffeine). More often than not, these doses were doubled for a 'better buzz'...I got caught in the flow trying to be like the older guys on the team. I often felt side effects from taking larger doses of pre-workout, e.g. light-headedness, heart palpitations (exacerbating my pre-existing arrhythmia), and tingling in the fingers and toes"...

Student no. 4---"When people learn that I do not drink coffee and, in fact, dislike the taste, they are incredulous. One time, in college, one of my friends dared me to drink really strong coffee... The severe headache I got after drinking that only strengthened my dislike for the drink and my resolve to never get into the habit of using it".

\section{Caffeine and the cardiovascular system}

A bolus of hot liquid passing through the esophagus near the heart (because of their physical proximity) can disturb electrical activity in the specialized cardiac conduction system. The disturbances are easily monitored on an electrocardiogram, and at the very least include unstable and wandering isoelectric baselines. We have observed this and related cardiovascular effects with hot beverages and caffeine in young adults 
[16-19]. After a cup of hot coffee has been stored in the stomach, it reflexly affects peripheral blood flow and other circulatory hemodynamics. Beyond these reflex effects, and after caffeine has been absorbed and is being delivered to the organs and tissues, marked peripheral vasoconstriction and accompanying reductions in blood flow occur (a non-reflex, direct effect of caffeine) [16-19].

An overheated stomach sends neurohumoral messages to the central nervous system alerting it that there has been an increase in core body temperature. Reflexly, the superficial blood vessels (e.g. in apical skin) vasodilate to help eliminate rather than store the excess heat. This vasodilation and attendant increase in blood flow are easily monitored in fingers and toes [20-23]. Depending on the volume of hot fluid consumed, and its temperature, peripheral vasodilation can last 15-30 minutes or more. After the body has eliminated the excess heat, a prominent peripheral vasoconstriction can also be monitored. This is a compensatory, heat-conserving response to the initial, heat-induced reflex. Hot drinks can and do upset the physiological homeostasis of thermoregulation in the body.

The cardiovascular blood flow response to caffeinated hot beverages has two components. The first is due to heat; the second results from caffeine's direct vascular actions. Thus, there are both direct and indirect cardiovascular effects that result from consuming caffeinated hot beverages. Any hot liquid, including pure water, when stored in the stomach, will provoke the thermoregulatory reflexes I have just described. This is evident when one compares caffeinated hot drinks such as coffee with non-caffeinated hot water [16]. Caffeine, on the other hand, is a direct vasoconstrictor and hot water is not.

\section{Caffeine's vascular mechanism of action}

Caffeine's primary mode of action is blockade of vascular adenosine receptors. Adenosine is a naturally-occurring, continuously-released, physiologically-important, and relatively-potent vasodilator [24-34]. It vasodilates by binding to adenosine receptors on vascular smooth muscle and by causing the smooth muscle cells to relax [25]. It cannot do this when adenosine receptors are occupied by caffeine and other methyl xanthines, all of which are adenosine receptor antagonists.

In other experiments we have asked subjects to consume caffeine containing tablets of 200-400 mg (simulating the doses the addicted get in one or two cups of coffee/large energy drinks, etc.). Routinely and within as little as fifteen minutes we see caffeine-mediated peripheral vasoconstriction. This is revealed by graded, marked, and time dependent decrements in monitored blood flow even when arterial perfusion pressure is maintained. These decrements in blood flow are caused by the drugs prominent vasoconstrictor actions which again are due to blockade of adenosine receptors [26-29]. With 200-400 mg caffeine, the vasoconstriction lasts at least 45-60 minutes and can, in some cases, reduce digital flow to near zero [16-19]. Such limited blood flow can cause ischemia and hypoxia. If sustained, tissue necrosis and permanent damage can result [30-34]

\section{Summary and conclusions}

Casual observations might convince an extraterrestrial visitor that the consumption of coffee is as essential to life on earth as is respiratory minute ventilation. Yet, well-informed readers know the only liquid required physiologically by the body is water. Decades ago on the written portion of my Ph.D. prequalifying examinations a renal physiologist asked me to discuss the physiology of water. He was the first to teach me that no other liquid is required by the mammalian body. $\mathrm{He}$ also contributed importantly to my excellent graduate school education by teaching me renal physiology and serving on my guidance committee.
I wonder if caffeine-addicted humans could replace their coffee with water would they be better off physiologically? For certain they might save money. Arguably, they could even save time (no more waiting on lines at Starbucks/Dunkins). Would job efficiency and productivity suffer? Beyond the period of withdrawal what kind of person would each become? If I was sufficiently persuasive as a writer, I would convince my readers to try the experiment. One might be pleasantly surprised by the outcome.

\section{References}

1. Barone JJ, Roberts HR. (1996) Caffeine consumption. Food Chem Toxicol. 34:119-129.

2. Daly JW, Fredholm BB. (1998) Caffeine: an atypical drug of dependence. Drug Alcohol Depend. 51:199-206.

3. Fredholm BB, Battig K, Holmen J, Nehlig A, Zvartau EE. (1999) Actions of caffeine in the brain with special reference to factors that contribute to its widespread use. Pharmacol Rev. 51:83-133.

4. Frary CD, Johnson RK, Wang MQ. (2005) Food sources and intakes of caffeine in the diets of persons in the United States. $J$ Am Diet Assoc. 105:110-113.

5. Lee, C. (2018) The science behind the world's most popular drug.

6. Ramanathan C, Ekpenyong L, Stevenson JH. (1994) Scald burns in children caused by hot drinks: the importance of the type of cup. Burns. 20:111-114.

7. Brown, F, Diller KR. (2008) Calculating the optimum temperature for serving hot beverages. Burns. 34:648-654.

8. Monstrey S, Middelkoop E, Vranckx JJ, BassettoF, Ziegler UE, et al. (2014) Updated scar management practical guidelines: noninvasive and invasive measures. J Plast Reconstr Aesthet Surg. 67:1017-1025.

9. Loller C, Buxton GA, Kerzmann TL. (2016) Hot soup: correlating the severity of liquid scald burns to fluid and biomedical properties. Burns. 42:589-597.

10. Finnerty CC, Jeschke MG, Branski LK, Barret JP, Dziewulski P, et al. (2016) Hypertrophic scarring: the greatest unmet challenge after burn injury. Lancet. 388:1427-1436.

11. Heatherley SV, Hancock KM, Rogers PJ. (2006) Psychostimulant and other effects of caffeine in 9 to 11 year-old children. $J$ Child Psychol Psychiatry. 47:135-142.

12. Cappelletti S., Piacentino D., Sani G. and Aromatario M. (2015) Caffeine: cognitive and physical performance enhancer or psychoactive drug? Current Neuropharmacology.13: 71-88.

13. Ferré, S. (2016) Mechanisms of the psychostimulant effects of caffeine: implications for substance use disorders. Psychopharmacology, 233: 1963-1979.

14. McLellan TM, Caldwell JA and Lieberman HR. (2016) A review of caffeine's effects on cognitive, physical, and occupational performance. Neuroscience and Biobehavioral Reviews. 71: 294312.

15. Peck J., Tenenbein M., Weaver C. and Wikoff D. (2018) Key findings and implications of a recent systematic review of the potential adverse effects of caffeine consumption in healthy adults, pregnant women, adolescents, and children. Nutrients. 10:1536-1552.

16. Merrill GF, Sharp, VA. (2018) Undesirable cardiovascular effects of hot drinks. Int'l Jou Clin Med Cases, 1:117-124.

17. Merrill GF, Costea DM, Sharp VA. (2019) Caffeine and reactive hyperemia. World J Cardiovas Dis. 9:437-448.

18. Merrill GF, Costea DM, Sharp VA. (2019) Caffeine and pressure flow autoregulation. World J Cardiovas Dis. 9:253-266.

19. Merrill GF, Joshi H. (2020) Caffeine and peripheral blood flow, J. Clinical Medical Reviews and Reports 2(2).

20. Montgomery I, Jenkinson DM, Elder HY, Czarnecki D, MacKie RM. (1985) The effects of thermal stimulation on the 
ultrastructure of the human atrichial sweat gland. Br J Dermatol. 112:165-177.

21. Charkoudian N. (2010) Mechanisms and modifiers of reflex induced cutaneous vasodilation and vasoconstriction in humans. $J$ Appl Physiol. 109:1221-1228.

22. Johnson JM, Minson CT, Kellogg DL Jr. (2014) Cutaneous vasodilator and vasoconstrictor mechanisms in temperature regulation. Compr Physiol. 4(1):33-89.

23. Inoue R. (2016) New findings on the mechanism of perspiration including aquaporin-5 water channel. Curr Probl Dermatol. 51:11-21.

24. Berne, R.M. (1964) Regulation of Coronary Blood Flow. Physiological Reviews, 44, 1-29.

25. Feigl, E.O. (1983) Coronary physiology. Physiological Reviews, 63, 1-205.

26. Olsson, R.A., Davis, C.J., Khouri, E.M. and Patterson, R.E. (1976) Evidence for an adenosine receptor on the surface of dog coronary myocytes. Circulation Research. 39: 93-98.

27. Burnstock, G. (1980) Purinergic receptors in the heart. Circulation Research. 46:175-182.
28. Mustafa, S.J. (1980) Cellular and molecular mechanism(s) of coronary flow regulation by adenosine. Molecular and Cellular Biochemistry, 37: 67-87.

29. Dutta P. and Mustafa S.J. (1980) Binding of adenosine to the crude plasma membrane fraction isolated from dog coronary and carotid arteries. Journal of Pharmacology and Experimental Therapeutics. 214: 496-502.

30. Liu H, Xia Y. (2013) Beneficial and detrimental role of adenosine signaling in diseases and therapy. J Appl Physiol. 119:117311821985.

31. Eisenstein A, Patterson S, Ravid K. (2015) The many faces of the A2b adenosine receptor in cardiovascular and metabolic diseases. J Cell Physiol. 230:2891-2897.

32. Nijjer SS, Sen S, Petraco R, Davies JE. (2015) Advances in coronary physiology. Circ J. 79:1172-1184.

33. Hoiland RL, Bain AR, Rieger MG, Bailey DM, Ainslie PN. (2016) Hypoxemia, oxygen content, and the regulation of cerebral blood flow. Am J Physiol Regul Integr Comp Physiol. 310:R398R413.

34. Hearon CM Jr, Dinenno FA. (2016) Regulation of skeletal muscle blood flow during exercise in aging humans. J Physiol. 594:22612273. 